\title{
Friend Not Foe: The Role of Curriculum Committee in Supporting the Development of Curriculum at Royal Roads University
}

\author{
Michael G. Young \\ School of Humanitarian Studies, Royal Road University, Canada
}

Copyright (C) 2015 by authors, all rights reserved. Authors agree that this article remains permanently open access under the terms of the Creative Commons Attribution License 4.0 International License

\begin{abstract}
Curriculum Committee at Royal Roads University (RRU) is mandated with ensuring that program and course curricula are of sufficient high academic integrity, consistent with other academic institutions, delivered in a manner consistent with program outcomes, and align with the recently adopted Learning and Teaching Model. Yet, the apparent simplicity of the committee's role is overshadowed by much confusion about what the committee does, how and why it does what it is intended to do and whether it is effective in fulfilling its mandate. This paper explores the role of Curriculum Committee at RRU regarding the tensions that the committee encounters fulfilling its role. It begins with an historical review of Curriculum Committee, which is followed by a look at some of the factors that influence decision-making during committee meetings. Next, it examines the tensions posed by trying to strike a balance between form, function and the context of curriculum proposals. The paper concludes with an observation that Curriculum Committee continues to evolve as it incorporates the lessons learned from ongoing self-reflection and feedback from faculty members and the broader university.
\end{abstract}

Keywords Curriculum Committee, Development, Learning and Teaching Model, Quality Assurance

\section{Introduction}

At first glance, the role of Curriculum Committee (CC) at RRU seems relatively uncomplicated, even straightforward. As a subcommittee of Academic Council, it operates on the basis of the Curriculum Quality Assurance policy, which provides that curriculum is (1) of an appropriately high academic quality, (2) consistent with standards at other accredited Canadian universities, and (3) designed and delivered in a manner consistent with program outcomes [1]. Essentially, and on an operational level, the committee is mandated with reviewing program and course curricula, making suggestions for change, and forwarding approved curricula to Academic Council.

Despite the apparent simplicity of the committee's role, there has been significant criticism from curriculum developers about the committee's approach to the curriculum review process. Perceptions of the committee range from one of annoyance, wherein attending a committee meeting is considered a waste of time, to one of resignation, where the experience is something to be endured before getting on with the real job of teaching. Others typify the committee as a star chamber comprised of members who seek to indict, convict and punish curriculum developers who stray from the way curriculum is supposed to be. In reality, only recently has $\mathrm{CC}$ developed a template that speaks to the needs of curriculum developers regarding the breadth and scope of material required for a proposal [2]. Even more recent is a rubric developed by $\mathrm{CC}$ for assessing the content of proposals. Yet, the role of the committee has not changed since its inception, neither has its essence. Curriculum Committee exists to ensure that all curricula deliver on the promise of academic quality, including the learning and teaching model at RRU.

Based on conversations with previous curriculum chairs and the observations of the author, the current chair, this paper explores the tensions that $\mathrm{CC}$ encounters in fulfilling its role. We begin by outlining the history of $\mathrm{CC}$. Next, we look at some of the factors that influence decision-making during committee meetings. We also examine the tensions posed as the committee tries to strike a balance between form, function and the context of curriculum proposals. We conclude by noting that $\mathrm{CC}$ continues to evolve as it incorporates the lessons learned and ongoing self-reflection, and by implementing best practices into the review process. A key aspect to this evolution is to support of curriculum developers by instilling a sense of distributed responsibility for curriculum development. Distributed responsibility is meant to lessen the potential isolation experienced by curriculum developers and to provide resources in terms of pedagogical expertise, particularly in the online context. 
The emerging curriculum development triad - curriculum developers, the committee and the learning and teaching model - share a common goal delivering high quality programming at RRU [3]. Whether or not the committee, in its early days, ever dictated what was to be in curriculum, as some thought it did, its current focus is on how any proposed curriculum delivers on the promise of the learning and teaching model at RRU.

\section{In the Beginning}

Prior to the establishment of Curriculum Committee in the early 21 st century, curriculum proposals were reviewed and approved directly by Academic Council (AC). AC approval of criteria such as learning outcomes and the quality of curriculum were assessed by the Program and Research Committee (PRC), which worked at arms' length of AC [4]. Given RRU's status as a special purpose university under the Royal Roads University Act (1996), program and curriculum development were subject to intense scrutiny and assessment by the B.C. Ministry of Advanced Education [5]. The more traditional establishment of university status based on faculty curriculum vitae, including research and publication record, was supplanted by a desire to ensure the quality of curriculum and program development. In essence, academic units at the university were held responsible for producing the highest quality of curriculum possible within the confines of the very specific mandate of this new institution. Lacking a comprehensive history of program and course development, RRU was at a disadvantage in terms of expertise and resources.

Under the stewardship of former Academic Vice President, Ron Bordessa, the responsibilities of AC were hived off into three separate entities. In an interview with the first committee chair, S. Grundy, PhD (March, 2014) then a professor in the School of Environment and Sustainability and one of the founders of the university, CC was the first to emerge in this new arrangement. Yet, program and curriculum development was not exempt from provincial oversight. Indeed, provincial scrutiny continued for over ten years after the university's inception, and push back from the ministry continued, for example, in the development of new programming. According to previous members, $\mathrm{CC}$ was informally tasked with raising the bar of program and curriculum development demanding more from curriculum developers than would be expected at a more traditional university. In a conversation with Professor D. Hamilton, PhD (March 2010) for developers, CC's role as guardian of quality translated into higher expectations for program and course proposals and the corresponding work involved.

It may be argued that the expectations placed on developers resulted in solid, well-planned curriculum design. However, the early years of CC were not without struggles between developers and the committee. A large portion of the apparent friction was the result of RRU's status as a special purpose university. A focus on applied graduate programming and undergraduate degree completion required unique approaches to programing and to pedagogy. Not surprisingly, program and curriculum development did not always resemble those of other institutions. Thus, producing proposals that passed the rigors of CC could be and remains a challenge to developers. Producing the highest quality of curriculum possible required that $\mathrm{CC}$ establish and maintain credibility with the province and other academic institutions [6].

As the university grew in terms of reputation and popularity, the second Chair of CC, a Doug Hamilton, started to move the committee towards a model of inclusion rather than gatekeeper, a common perception at the time. Professor D. Hamilton, PhD (March 2014) commented that this became more possible as the Ministry of Advanced Education, the body tasked with oversight, appeared satisfied that the university had established an effective and efficient curriculum development process. While this was an informal and perhaps subtle transformation, the emphasis was to be on the shared learning experience of those in the curriculum development process. The committee attempted to offer advice, before potential developers submitted proposals, and the Centre for Teaching and Education Technology (CTET) joined the process [7]. Although it could be concluded that this development occurred too late in Dr. Hamilton's term to be fully adopted/accepted by faculty members, it did establish parameters on which his successors would re-craft and continue to promote.

\section{Curriculum Committee Today}

Curriculum Committee comprises representatives from several units of the university including six faculty members, with at least two from the Faculty of Management, at least two from the Faculty of Social and Applied Sciences; the Deans or designates from those faculties; a representative from CTET; the Registrar; and a non-voting secretary, while some roles are ex-officio, and therefore ongoing, the six faculty members are elected through the Registrar's Office [8]. The committee meets on Tuesdays twice a month for 2.5 hours. Meetings follow a typical model based on Robert's Rules and require four voting members for quorum.

Central to the development process was the adoption of a curriculum template in 2012. The template is divided into two parts, $\mathrm{A}$ and $\mathrm{B}$, which distinguishes between what can be considered immutable course outline material, part A, and more detailed content, part B, developed for the course shell in Moodle, the online delivery platform used by RRU. Developers are encouraged to follow the suggestions on the template, and to consult with CTET, and other units in the university such as the Library, Office of Research and Registrar's Office, regarding curriculum design and delivery. 
Admittedly, the development of course outlines and, to lesser degree, program proposals are not straightforward or linear processes. It is not possible to outline all of the stages of this process, but a few salient points are worth mentioning here. Regarding course outlines, the process follows an iterative model wherein the developer has the outline approved by the Program Head, who then forwards the proposal to the school director. Once approved at this level, the director forwards it for approval by the appropriate faculty dean who asks the $\mathrm{CC}$ chair to place the proposal on the meeting agenda. At any of these stages the proposal can be returned to the developer for amendment. Recently, an editor was added to the process to reduce the amount of time spent at $\mathrm{CC}$ meetings dealing with issues related to presentation, such as grammar, diction and the like. Once a proposal has completed all of the above stages, it will be forwarded for review to the members of Curriculum Committee, who will share their observations in the regular meetings.

\section{How Decisions are Made}

Decision making in $\mathrm{CC}$ is based on a vote requiring greater than 50 percent to pass a course program proposal, including changes to programs. In the event of a split, the chair is responsible for casting the tiebreaker. Decisions are commonly made in consensus, based on the content of the proposal in terms of alignment with the program, school, faculty and Learning and Teaching Model (LTM) at RRU. Developers present their outlines or program changes at the meeting and, essentially, the committee uses the preceding criteria to assess the quality of the proposal. The core components of the Leaning [9] include the following key reference points:

- Outcomes Based
- Experiential and Authentic
- Learning Community
- Inam-Based
- Applied
- Engaged Learning
- Action Research
- Supportive
- Flexible

Prior to submission to the committee, developers are encouraged to work with CTET on curriculum matters, learning outcomes, and to have a CTET representative in attendance at the meeting. At the moment, program heads are invited to attend, but their presence is not required. The meeting process is intended to be inclusive and collegial, but the committee recognizes that some developers view the process as somewhat adversarial. It is assumed that the history of CC's role as guardians and gatekeepers of curriculum is responsible for this impression, and CC is looking to improve the reputation it has inherited.
Regarding the LTM, the focus on what is called "authentic learning" at RRU brings with it a broader definition and understanding of what appropriate curriculum looks like. While the 11 components of the LTM strategy broaden the scope of postsecondary education, their prominence also brings ambiguity, which $\mathrm{CC}$ must sort through in the curriculum review process. As the committee has discovered, there can be a fine line between innovative program and curriculum development and academic rigour. It is not the CC's role or desire to prevent or eliminate innovation, but it is important to maintain academic standards that are acceptable to the broader academic community at the same time. Finding the right balance is further challenged by the format of the course outline submissions, which often resemble a syllabus or even course minutiae rather than a simple outline.

\section{Going Forward}

Given the move towards an inclusive curriculum development process starting with Doug Hamilton and the emphasis on collegiality, the way forward is relatively clear. The curriculum development triad consisting of developer, which includes the involvement of CTET from the outset, committee and LTM stands to ensure the continued high standard of curriculum development at RRU (see Figure 1). That said, it behooves the committee to emphasize and practise inclusiveness and collegiality. Curriculum Committee has been working to find ways to reach out to faculty curriculum developers, initially by developing the proposal templates accompanied by some helpful notes, and we anticipate the adoption of additional strategies to engage present and future curriculum developers. This function has been identified more frequently in recent planning workshops as crucial for $\mathrm{CC}$ as it works to reimagine its relationship with curriculum developers in supporting innovation alongside its mandate to maintain academic quality and rigour. As well, the ongoing functioning of $\mathrm{CC}$ and its continued evolution depends on the willingness of potential committee members to participate, which will presumably be enhanced as its goals and activities become more transparent and widely understood.

Another feature of the curriculum development process to be explored is the possible expansion of CTET's role in the curriculum development process. Initial discussions with CTET focusing on curriculum excellence as a function distinct from CC review would have implications for curriculum development. As a separate but connected entity, a body focusing on curriculum excellence would transform the curriculum review process substantially. Ostensibly, this development would dovetail with the changes currently being made to the curriculum development template. The main change being considered involves dividing the template into three sections. Section A, including the identifying characteristics of the course such as name and number and calendar description as well as the section on 
learning domains or competencies and learning outcomes, would remain the same, but section B would be reduced to include only the course overview and the assessment matrix, the assignment and evaluation descriptions and the course readings and resources, leaving the unit descriptions for section C. Section A would be technically immutable, meaning that changes made in this section would need the approval of CC. Changes could be made to section B with approval of the School Director and or the Dean. Meanwhile, the new section $\mathrm{C}$ would allow developers to work with CTET to craft a course syllabus that could be loaded into a course shell. This is not to say that CC would ignore section $\mathrm{C}$ when the course outline is initially considered, but to emphasise the point that delivery should presumably be more malleable and subject to change and thus requiring more flexibility in terms of faculty intervention and development. Program revisions would not be affected by this change.

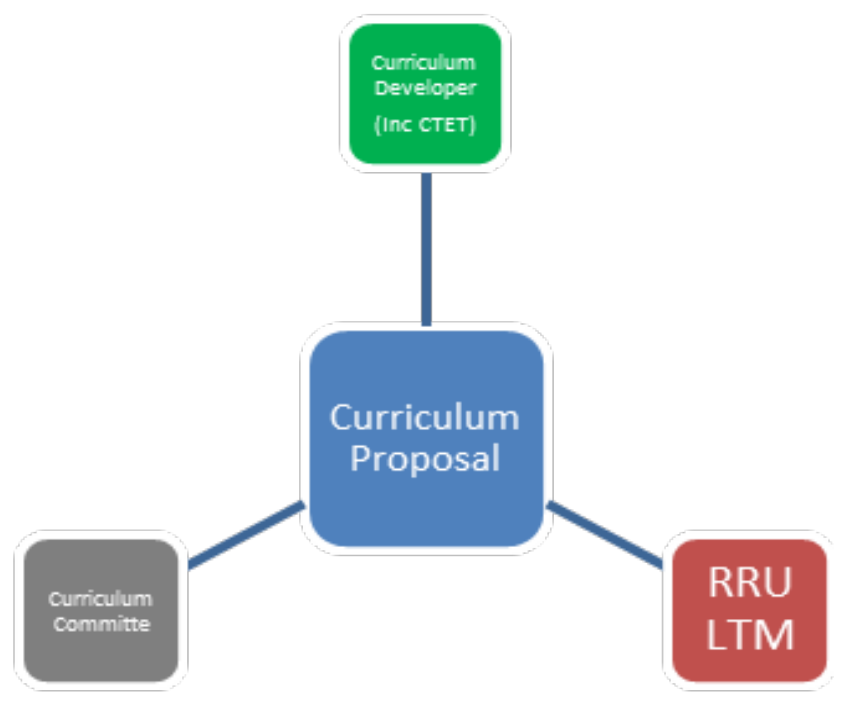

Figure 1. Curriculum Development Triad

\section{Conclusions}

Since its inception, CC has been tasked with overseeing the development of programs and course outlines. Arguably, as a result, course outlines at RRU have been subjected historically to more scrutiny from outside the university than would be experienced at other institutions. This scrutiny has presumably resulted in higher quality program and course curriculum. Presently, the Ministry of Advanced Education seems satisfied with the operation of the university, and outside scrutiny of program and curriculum development has abated. Yet success on this front has sometimes served to somewhat alienate $\mathrm{CC}$ from faculty. That said, in the spirit of collegiality, efforts to include faculty in the curriculum process will continue. Indeed, the development of a three-part course outline template signals the continued desire of $\mathrm{CC}$ to work with faculty before proposals come to committee and to introduce more flexibility in the curriculum design process. Moreover, the active support of CTET in the design process and its renewed focus on curriculum excellence should lead to new levels of communication and cooperation in the curriculum development triad.

\section{Acknowledgements}

The author would like to thank the participants in this research, and Mr. Peter Dueck and Dr. Eva Malisius for their comments on an earlier draft of this paper. The comments from anonymous referees are also appreciated.

\section{Notes}

Contact the author if interested in the most recent edition of the proposal template.

\section{REFERENCES}

[1] Quality Assurance Policy [Internet] Victoria, 2007 [cited 2015 Oct 19]. Available from: http://www.royalroads.ca/sites/default/files/u144/rru quality _assurance_policy_-_june_2007_.pdf

[2] Academic Governance [Internet] Victoria, 2015 [cited 2015 Oct 13]. Available from:

http://www.royalroads.ca/about/academic-governance

[3] Learning and Teaching Model [Internet] Victoria, 2014 [cited 2015 Oct 19]. Available from: http://media.royalroads.ca/media/marketing/viewbooks/2013 /learning-model/index.html?pageNumber $=1$

[4] Academic Governance [Internet] Victoria, 2015 [cited 2015 Oct 13]. Available from:

http://www.royalroads.ca/about/academic-governance

[5] Royal Roads University Act [Internet] Victoria, 1996 [cited 2015 Oct 12]. Available from:

http://www.bclaws.ca/Recon/document/ID/freeside/00_9640 901

[6] Academic Governance [Internet] Victoria, 2015 [cited 2015 Oct 13]. Available from:

http://www.royalroads.ca/about/academic-governance

[7] Centre for Teaching and Educational Technology [Internet] Victoria, 2015 [cited 2015 Oct 12]. Available from: http://ctet.royalroads.ca/

[8] Curriculum Committee [Internet] Victoria, 2015 [cited 2015 Sept 12]. Available from:

http://ctet.royalroads.ca/curriculum-committee

[9] Learning and Teaching Model [Internet] Victoria, 2014 [cited 2015 Oct 19]. Available from:

http://media.royalroads.ca/media/marketing/viewbooks/2013 /learning-model/index.html?pageNumber $=1$ 